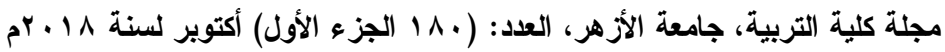

\title{
Students' Environmental Paradigms: A Cultural Perspective
}

\begin{abstract}
:
The nature of the world's environmental challenges has changed considerably in recent decades. Environmental education is the primary shield against continued climate change. This study explores students' environmental paradigms from a cultural perspective. The study sample consisted of 322 male and female students from Kuwait University; the scope was twofold: gender and environmental knowledge. A self-administered survey questionnaire was used to collect the necessary data. The findings were as follows: 1) a valid and reliable Arabic form of New Environmental Paradigm scale was verified; 2) Dual beliefs appeared in the sample population's responses about all aspects of the environmental paradigms; 3) Subjects showed the strongest agreement with assertions regarding the possibility of an eco-crisis and the fragility of nature's balance. The greatest relative disagreement was with statements related to the reality of limits to growth; 4) pre-exposure to environmental courses has impact on students' responses to NEP scale; 5) Females only scored higher (with a high score representing a pro-ecological belief) than did males. The researchers concluded that an environmental scale should be carefully constructed and evaluated with respect to characteristics of the cultural context, and especially the religious beliefs of the population being studied.
\end{abstract}

Keywords Environmental beliefs, Ecology advocacy, Kuwaiti environmental perception, Environmental ethics

\section{Introduction:}

The nature of environmental challenges has changed considerably in recent decades. Increasingly, the call has been raised for a global response to worldwide environmental issues that now affect all life on earth. The United Nations (UN) addressed sustainable development, and declared it to be their primary emphasis, at least for the next ten years (Buckler \& Creech, 2014). Global environmental problems include issues such as pollution, loss of biodiversity, global warming, ozone depletion, and tropical deforestation (Lotz-Sisitka, 2015). In addition, the world has seen nuclear accidents, oil spills, the mismanagement of solid and hazardous waste, depletion of resources, environmental deterioration, global warming, environmentally-induced diseases, and other ecological problems since the 1970s (Erdogan, 2009). With mounting awareness of the planet's environmental difficulties, it is now recognized that humans are far from immune 
to ecological complications (Tasking, 2009); future generations and the ecosystem as a whole are clearly in jeopardy. As such, the issue of environmental protection has gained substantial national and international attention.

The 2014 UNESCO summit in Nagoya, Japan, and the launch of the United Nations' Decade of Education for Sustainable Development (DESD) (2005-2014) was accompanied by a series of high-profile events and celebratory activities around the world (Lotz-Sisitka, 2015). The Kuwaiti government has attached great importance to and care for the implementation of 17 sustainable development goals resulting from this global sustainable development summit meeting, as have numerous other world leaders. Education for Sustainable Development 2030 is the theme of the UN's Goal 4.3 (Messiou, 2017). Now, in 2018, a global action program for the adoption of an official declaration is to be put into action. Wrestling with environmental problems is no longer the exclusive concern of scholars or specialists; it is now of widespread importance to the public. People are increasingly expressing concern for their quality of life and have become more thoughtful about the impact of environmental issues on their existence (Al Kandari, 2016). Therefore, stakeholders must now wrestle with the following questions: What is the impact of the UN's DESD efforts on education? What difference does it make? How can progress in education for sustainable development (ESD) be assessed? To what extent are environmental problems considered to be the responsibility of individuals, as consumers and citizens? These questions have become more prevalent in recent years, as the alarms warning of an obligation to educate about sustainable development have grown louder (Buckler \& Creech, 2014; Sharifi \& Murayama, 2014; Lotz-Sisitka, 2015). Individuals do share substantial responsibility for the current state of the environment. There is much knowledge that has been collected regarding the causes of environmental problems, and citizens in many societies are well informed about their role in contributing to the current state of the earth. Yet many people still choose to behave in ways that contribute to the situation, and ignore the alternatives and their environmental benefits. As individuals, however, we are morally responsible. The urge to ascribe responsibility stems from the belief, or paradigm in individual capabilities, whether based in knowledge, potential, or power. As has been argued by Putrawan (2015), there are two kinds of paradigms perceived by human beings in relation to the environment. The Dominance Social Paradigm (DSP) is characterized by the belief that it is acceptable for an ecosystem or environment to be destroyed because it has the ability to recover by itself. According to this paradigm, natural resources are unlimited, so they may be used irrationally to fulfil basic human 
needs. Humans have power over nature, which in science is called anthropocentrism. Conversely, the New Environmental Paradigm (NEP) has characteristics opposite to those of the DSP. The NEP assumes that human beings are a part of the greater ecosystem, and natural resources are very limited; they must be used carefully or they are at risk of extinction. This paradigm teaches us to love our natural surroundings, take responsibility for their wellbeing, and live with them harmoniously.

Environmental education seeks to offer instruction on appropriate environmental attitudes, behaviors, ethics, and beliefs. The NEP is one of the predominant scales developed by Dunlap and van Liere (1978) to predict environmental attitudes and behaviors. It is considered to be an accurate measure of an individual's environmental worldview or paradigm. The NEP scale is widely used (Dunlap, 2008). It consists of five dimensions; a short description of each is as follows:

1. Balance of Nature: the belief that human activity affects the balance of nature.

2. Eco-crisis: the belief that humans are causing detrimental harm to the physical environment.

3. Anti-exemptionalism: the belief that humans are not exempt from the constraints of nature.

4. Limits to Growth: the belief that the earth has limited resources.

5. Anti-anthropocentism (human domination): the belief that human beings have the right to modify and control the natural environment (Dunlap, 2008).

Hawcroft and Milfont (2010) used the NEP scale to produce a meta-analysis of research conducted over the last 30 years. A review of 69 studies from 36 countries, including 56,279 participants from 139 samples, showed that there is considerable variation in the way the NEP scale is used, particularly with regards to the number of items listed and points on the Likert scale employed. Different studies have demonstrated a wide range of approaches to using the collective scores (Dunlap, 2008; Hawcroft \& Milfont, 2010). The scales were frequently used as a foundation for education and planning for developing environmental awareness.

These conclusions were supported by a number of studies. For example, Rexeisen and Roffler (2006) found changes in students' attitudes toward the physical environment, and that study abroad had a positive impact on a student's eco-worldview. Students' attitudes were also found to continue to evolve and 
change after returning to their home institution, in some instances exhibiting unexpected improvement. In other cases, there was evidence of a decline in positive attitudes toward the environment. Gender was determined to be a significant moderator of attitude towards the environment (Zelezny, Chua, \& Aldrich, 2002). Thapa (1999) found that females scored higher than males on the NEP scale (with a high NEP score representing an attitude that endorses an ecological worldview), which could be attributed to women traditionally sharing more of the burden for housework and other domestic activities. Al Kandari (2016) stated that women reported stronger environmental attitudes and more positive behaviors than men. A similar conclusion was drawn in Rice's study of pro-environmental behavior in Egypt (2006). Explanations for gender differences in environmentalism have included that females have higher levels of socialization and thus are more oriented towards being socially responsible (Al Kandari, 2016).

Hawcroft and Milfont (2010) found that NEP scores correlated with a wide range of national characteristics and national-level rankings of social and psychological attributes obtained from prior cross-national studies. They surmised that public awareness and environmental orientation were highly related to an individual's socialization process, education, media exposure, and level of familial interaction. Olofsson and Ohman (2006) examined general beliefs and environmental concerns in the United States, Canada, Norway, and Sweden. They concluded that "general beliefs, together with education and political affiliation were the most stable predictors of environmental concern."

Ustun, Kalkavan, and Gümüşgül (2013) determined that the environmental attitudes of 540 university students participating in outdoor recreation were in favor of nature, while Erdogan (2009) found no widespread support for the NEP. Only $56.0 \%$ of the students surveyed were pro-NEP. Ardahan (2012) found significant differences in whether or not respondents were in favor of active recreational participation in outdoor sports. Rideout (2014) identified a significant difference in NEP scores attributable to academic year, class status, and gender. Females in their sample consistently demonstrated more pro-environmental views. The above-mentioned studies contributed empirical support to the validity and suitability of the NEP scale, buttressing the predictive power of this tool. 


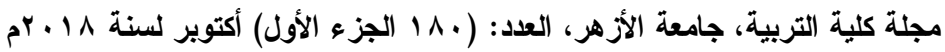

\section{Religion Context of the Environment Paradigm:}

Environmental ethics is a philosophical discipline that studies the moral relationships among human beings with, and the value and status of, the environment and its non-human contents. Major or minor, extinct or thriving, most religions give relevance to the environment and the relationship of human beings with the Earth. The modern Abrahamic religions of Judaism, Christianity, and Islam all revere the environment and recognize its significance within their respective religious texts (Hammink, 2012). In Islam, the worldview is inclusive, comprehensive, and holistic; it encompasses all creatures in place (wherever they exist) and time (this life and the afterlife). It also describes the Almighty's supervision for the regulation of behavior (balance). The Qur'an relates the story of creation and the relationship of humans with their environment, providing a rationale for behavior (why), a proscribed set of actions (what), established standards (how), and distinct roles and responsibilities (who), within the ultimate context of faith (motivation and mood) (AlDhamkhi, 2008). Muslims believe that Allah created everything in the universe in due proportion and measure, both quantitatively and qualitatively. It is written in the Qur'an: "Verily, all things have We created by measure" (Qur'an, 54:49). "Everything to Him is measured" (Qur'an, 13:8). "And we have produced therein everything in balance" (Qur'an, 55:7). Allah did not create anything in this world in vain or without wisdom, value, or purpose. Allah declared in the Qur'an: "We have not created the heavens and the earth and all that is between them carelessly. Therefore, humans are part of this universe and a distinct part of it as well, and have a special position among other living beings."

Humans must rise above their material nature stemming from their theomorphic makeup and the burden of trust, and have a good relationship with the environment. Human beings are ordered in the Qur'an to respect life and do their best to sustain it. Holding the trust of Allah, humanity is to be a caregiver to all aspects of life, and has no right to subject the lives of others to any danger; this is important not only for the sake of balance, but also to avoid dangerous repercussions that threaten human life and its quality (Bagader, El-Sabbagh, Al-Glayand, \& Samarrai, 1991). The Qur'an and its teachings define and clarify the relationship between humankind and the universe. As stated by Bagader et al. (1991), this relationship includes:

- Meditation, consideration, and contemplation of the universe and what it contains.

- Sustainable utilization and development of, and employment for, man's benefit and the fulfillment of his interests. 




- Care and nurture for man's good works, not limited to the benefit of the human species, but rather to the benefit of all created beings; "there is a reward in doing good to every living thing" (Sahih Al-Bukhari).

Thus, in Islam the utilization of resources is the right and privilege of all people and species. Therefore, people should take every precaution to ensure the interests and rights of all others, since they are equal partners on earth (Al-Damkhi, 2008; Risk, 2014). Similarly, individuals should not regard such behavior as being restricted to one generation above all others. It is, rather, a joint responsibility in which each generation makes the best use of nature according to its need, without disrupting or adversely affecting the interests of future generations. Therefore, humankind should not abuse, misuse, or distort natural resources, as each generation is entitled to benefit from them but not entitled to "own" them in an absolute sense (Knight, Seddon, \& Midfa, 2011).

This attitude towards the environment involves taking precautions to improve all aspects of life - health, nutrition, and psychological and spiritual dimensions - for humankind's benefit and the maintenance of its welfare, as well as for the betterment of life for all future generations. The Prophet declared it in his prophetic message: "If any Muslim plants a tree or sows a field, and a human, bird or animal eats from it, it shall be reckoned as charity from him" (Sahih Bukhari, 2009). Many scholars have highlighted the framework within which Islam approaches the topic of ecology, describing it as a faith-based stewardship of the earth. Shomali (2008) stated that some aspects of environmental ethics are based on an Islamic perspective, while Kamla, Gallhofer, and Haslam (2006) explained Muslim beliefs and practices regarding sustainable agriculture and permaculture, based on a transformative Islamic ecology. Islam and Islam (2015) considered the human-animal relationship, describing animal rights within the Islamic ecological paradigm. Also, Islam and Islam (2016) underscored an environmentalism of the poor, including how ecological disasters and environmental resistance can reach beyond borders.

Kuwait is an Islamic country. Islam is the official religion, and the majority of citizens are Muslim. Husain (2017) explained that religion had a level of influence throughout the transition to the nation's modern state, and has continued to maintain importance in Kuwaiti society as one of the defining features of the Kuwaiti identity. 


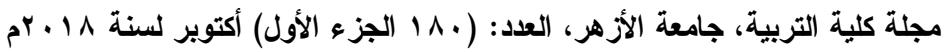

\section{Economic Context:}

Kuwait is a small, petroleum-based economy. The Kuwaiti dinar is the highest-valued unit of currency in the world (Silicon India, 2012). According to the World Bank, Kuwait is the fourth richest country in the world, per capita. Kuwait is the second richest GCC country per capita, after Qatar (World Bank, 2015). Its people are undergoing what might be called "a cultural shift" with regards to their lifestyle (Spiess, 2008; Wilson, Tyedmers, \& Pelot, 2007). Generally speaking, this is simply because Kuwaitis have enjoyed a comfortable and affluent lifestyle. The manifestation of so-called "cradle to grave" state-wide policy has been supported by the abundant transfer of oil wealth from the state to individuals who enjoy high GPD per capita incomes, which in the mild-2010s were estimated at $\$ 23500+$. Consequently, Kuwaitis have become empowered with the means to enjoy a high standard of living that is easily achieved since most of their necessities such education, housing, health care, water, electricity, phones, gas, and food staff are provided for them, either at heavily subsided rates or free of charge. A part from free public services and subsidized goods, the government provides individuals with generous grants, high salaries, and cheap loans. Coupled with these, no kind of taxation has been imposed upon Kuwaitis. Handsome wages, fringes, and increment benefits are paid to civil servants and this, in many cases, is regarded as a social subsidy element rather than an economic-based one. Employment is secure under the Constitution to all Kuwaitis regardless of their qualifications or the need for their services. Further, it is no exaggeration to say that getting married or refurbishing a house renders any Kuwaiti eligible for government cash and/ or easy loans. Given the high standard of living enjoyed by Kuwaitis, chance factors alone might determine which Kuwaitis would have or not have an environmental awareness and act or behave accordingly.

In 2035 strategical plan, the Kuwaiti government has pursued aggressive economic policies designed to reshape and modernize all aspect of life in Kuwait. Abdulaahi Husain (2017) explained that Kuwait has undergone a series of dramatic economic transformations in the past century. While much of the focus has been on the economy and society, it is also true that the Kuwaiti environment, and indeed the public perception of that environment, have also experienced rapid shifts during Kuwait's relatively short history as a modern country. Kuwait has embarked on a strategic plan for overcoming environmental challenges and problems. Its aims are to protect the environment and its natural resources, in order to maintain their integrity and development, as well as human prosperity. The strategy includes the following: 


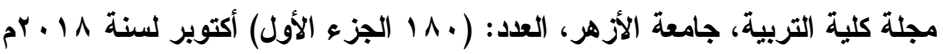

- Preserve the natural environment and its diversity, as well as natural and energy resources, and strive for their sustainable development.

- Establish the sustainable development of agricultural activities and livestock.

- Adapt urban and residential development and architectural features to current environmental conditions.

- Adopt a proper use of safe technology that does not adversely affect human health and the environment.

- Promote research in human resource development in environmental and resource protection.

- Support environmental awareness, education, and the development of human interaction with the environment for the protection and sustainability of development.

- Contribute to the protection of the global environment on a national scale.

- Establish environmental benefits to be among the basic considerations when approving and developing policies and resource development projects in various areas, and when determining the planning and development priorities of the State.

- Reduce the risk of environmental disasters on human health and safety, and the environment.

- Activate laws and regulations for the protection of the environment.

- Develop general directives for Kuwait's environmental strategy.

Kuwait focuses upon and exerts all of its efforts on protecting the environment not out of sensitivity from being an oil producing - and exporting - country, but because of an obligation and responsibility based on its role, both regionally and globally (Daramola \& Ibem, 2010; SUNSCO, 2017; Piess, 2008).

Inquiry into Kuwait's environmental context will prove helpful in moving towards a better understanding of these complex environmental problems. Many researchers have found proof of the impact of the economy on environmental issues, and indicated a positive and significant relationship between the two. Condrea and Bostan (2008), for instance, argued that the economy and environmental issues were interfering more and more with one another - on local, regional, national, and global levels -

$$
\text { -VYA- }
$$




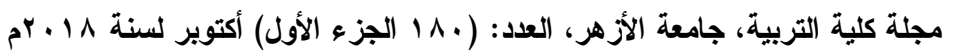

forming a network of cause and effect. Moreover, these researchers highlighted that economic premises and principles played a major role in shaping environmental policy. The importance of environmental values is also supported by economic evaluations (Demian, 2000; Plottu \& Plottu, 2007), and described in the Millennium Ecosystem Assessment (MEA, 2005). It can be concluded, then, that economics serve as a powerful tool for installing the ecosystem on the agendas of conservation and development decision-makers.

\section{Environmental Education Context:}

Kumud (2014) explained that Environmental Education (EE) is a life-long interdisciplinary process that is holistic both in nature and application. It concerns the interrelationship of humans and natural systems and encourages the development of an environmental ethics, sense of awareness, understanding of environmental problems, and critical thinking and problemsolving skills. EE teaches how natural environments function and how we, as humans, affect the environment through our behavior (Grimmeffe, 2014). Many people believe that EE is one of the most important factors in preventing further destruction of the environment (Ozden, 2008). In order to make formative decisions, students must not only become experts on the subject, but also develop a connection with the environment (Grimmette, 2014).

According to the North American Association for EE, as cited by Thompson and Hoffman (2003), EE is learner-centered and provides students with the opportunity to construct their own understanding through hands-on, minds-on investigations that engage learners in direct experiences and challenge them to use higher-order thinking skills. EE is supportive of the development of an active learning community where students share ideas and expertise. It is a process of infusing environmental content into the educational system in order to enhance awareness of environmental issues on all educational levels (Norris \& Juliet, 2016). EE helps to achieve an awareness and knowledge of environmental issues, as well as a positive attitude towards responsible environmental behavior. It has been a topic of scholarly review for the past twenty-five years. "It is generally agreed that $E E$ is a process that creates awareness and understanding of the relationship between humans and their natural ecology, man-made, cultural and technological. EE is concerned with knowledge, values and attitudes where has its responsibility on environmental behaviour" (Hafezi, Shobiri, Sarmadi, \& Abass, 2013). 
Norris and Juliet (2016) tested individuals' level of knowledge regarding, and attitude towards, the environment; test subjects were students of environmental education at Federal University in Edo, Nigeria. The results indicated a high level of knowledge about and positive attitude towards the environment among the surveyed; researchers also observed that the relationship between environmental knowledge and attitude was either negative, or there was little to no relationship at all. EE is the process of infusing environmental content into the educational system in order to enhance awareness of environmental issues at all educational levels (Norris \& Juliet, 2016).

Human activities play a vital role in the destruction of our environment. Therefore, the target of any pro-environmental programs must be human beings. Education is a tool for improving the level of awareness, amount of knowledge, attitudes, and even the personalities and behaviors of human beings regarding the environment. Over time, education has the power to change human behavior through the accumulation of knowledge and resulting changes in attitude and personality. Such a process of change runs concurrently with learning, socialization, and internalization of values, and thus it takes a long time to achieve its goal (Putrawan, 2015). If we want to effectively inspire change, we must work within the pattern of individuals' perceptions, and not merely address attitudes, skills, and behaviors. A quantum improvement will occur when we work within a paradigm (Covey, 2008). As can be seen from the above dialog, a number of factors imbedded in environmental context may have affected the Kuwaiti students' environmental awareness, attitudes, behaviors, and believes. Environmental paradigm is, in reality, a product of the interaction of all the above-mentioned factors.

In service of this goal, the research question for this study was formulated as follows: What are students' environmental paradigms as defined by using the NEP scale, based on their environmental background and gender? In addition, this research explored the phenomenon within a natural context, rather than provide an in-depth, multi-faceted picture.

\section{Significance of the study:}

Researchers in the current study assumed an interpretive approach, in an attempt to shed light on how certain aspects of individuals' identities affected their understanding of environmental problems. The goal was to determine the individual and shared social meanings of the dimensions accepted in the NEP, and provide an impetus for implementing "knowledge" in developmental planning for environmental awareness and attitudes. Some scholars in this field have argued that the key to

$$
-V r \cdot-
$$


environmental sustainability is the inclusion of a bottom-up approach, where individuals are encouraged to take action to develop their own environmental impact. Decision makers may find the current study helpful when evaluating policies, projects, and practices. In addition, having a valid and reliable Arabic copy of NEP scale is beneficial for educational, psychological, and sociological purposes.

\section{Study objective:}

This study explores and examines Kuwait University students' environmental paradigms, and expected variations in their perceptions attributable to gender and the extent of their exposure to ecological knowledge.

Study questions

1. Is the Arabic copy of NEP scale valid and reliable to measure Kuwait University students' environmental paradigms?

2. What are students' environmental paradigms, as measured by the NEP scale?

3. Do statistically significant differences exist in NEP scores that can be attributed to students' exposure to courses on the environment?

4. Do statistically significant differences exist in NEP scores that can be attributed to students' gender?

\section{Method and Procedure}

\section{Study population and sample}

The study population was comprised of 39,000 students at Kuwait University. A convenient sample $(N=322 ; F=224 ; M=98)$ from the population enrolled during the 2015, 2016, and 2017 academic years was selected. The subjects were stratified according to their respective levels of exposure to environmental courses: a) have no environmental course; b) have one environmental course; c) have master degree in environmental science.

\section{Methodology:}

Since the study examined students' environmental paradigms, a survey method was used to collect data. The New Environmental Paradigm scales were employed in the questionnaires, which divided the instrument into five facets, as follows: 
- Reality of Limits to Growth (RLG)

- Anti-anthropocentrism (ATR)

- Fragility of Nature's Balance (FNB)

- Rejection of Exemptionalism (ROE)

- Possibility of an Eco-crisis (POE)

\section{Measurement and analysis:}

The questionnaire used for this study was the NEP developed by Dunlap, (2008). It consisted of 15 items that were categorized into five dimensions: RLG (q1, q6, q11), ATR (q2, q7, q12), FNB (q3, q8, q13), ROE (q4, q9, q14), and POE (q5, q10, q15). A four-point Likert scale was employed to measure each item on the scale, as follows: $\mathrm{SD}=$ Strongly Disagree, $\mathrm{D}=$ Disagree, $\mathbf{A}=$ Agree, $\mathbf{S A}=$ Strongly Agree. For even-numbered questions, disagreement represented a pro-ecological view. For odd-numbered questions, agreement represented a pro-ecological view.

\section{RESEARCH FINDINGS}

1. Is the Arabic copy of NEP scale valid and reliable to measure Kuwait University students' environmental paradigms?

The scale was translated into the Arabic language, to help them to adequately understand the scale items, concepts, and meaning, the translation was necessary. It was verified via a back-translation method.

\section{NEP reliability:}

A Cronbach's Alpha analysis was used to test the reliability of the 15-item NEP scale and its five facets. The internal consistency reliability (alpha coefficient) ranged from 0.624 to 0.665. This meant that that the NEP scale yielded an acceptable level of score reliability when administered at different times, in various locations, and to the appropriate population. The mean alpha reliability coefficients are reported in Table (1). 
Table (1): Coefficient Alpha Reliability

\begin{tabular}{lc}
\hline \multicolumn{2}{c}{ Total Statistics per Item } \\
\hline \multicolumn{1}{c}{ Facet } & Cronbach's Alpha \\
\hline Reality of Limits to Growth & $\mathbf{0 . 6 2 4}$ \\
Anti-anthropocentrism & $\mathbf{0 . 6 4 8}$ \\
Fragility of Nature's Balance & $\mathbf{0 . 6 6 5}$ \\
Rejection of Exemptionalism & $\mathbf{0 . 6 3 4}$ \\
Possibility of Eco-crisis & $\mathbf{0 . 6 5 7}$ \\
\hline
\end{tabular}

NEP validity:

A Pearson correlation coefficient was used to explore the statistically significant correlations among the five dimensions of the NEP scale. The findings indicate that the correlations were statically significant; therefore, there were relationships among the five facets of the NEP scale survey. Details can be found in Table (2).

Table (2): Pearson Correlation Coefficients for the Five Facets of

\begin{tabular}{|c|c|c|c|c|c|c|c|}
\hline \multicolumn{2}{|r|}{ No: 322} & RLG & ATRS & FNB & ROE & POE & TOTAL \\
\hline \multirow{2}{*}{ RLG } & $\begin{array}{c}\text { Pearson } \\
\text { Correlation }\end{array}$ & 1 & $.207^{* *}$ & $.274^{* *}$ & $.143^{*}$ & $.180^{* *}$ & $.619^{* *}$ \\
\hline & Sig. (2-tailed) & & .000 & .000 & .010 & .001 & .000 \\
\hline \multirow{2}{*}{$\underset{\mathbf{S}}{\mathbf{A T R}}$} & $\begin{array}{c}\text { Pearson } \\
\text { Correlation }\end{array}$ & $.207^{* *}$ & 1 & .090 & $.257^{* * *}$ & .084 & $.573^{* *}$ \\
\hline & Sig. (2-tailed) & .000 & & .108 & .000 & .134 & .000 \\
\hline \multirow[t]{2}{*}{ FNB } & $\begin{array}{c}\text { Pearson } \\
\text { Correlation }\end{array}$ & $.274^{* *}$ & .090 & 1 & .086 & .081 & $.505^{* *}$ \\
\hline & Sig. (2-tailed) & .000 & .108 & & .124 & .147 & .000 \\
\hline \multirow[t]{2}{*}{ ROE } & $\begin{array}{c}\text { Pearson } \\
\text { Correlation }\end{array}$ & $.143^{*}$ & $.257^{* *}$ & .086 & 1 & $.241^{* * *}$ & $.621^{* *}$ \\
\hline & Sig. (2-tailed) & .010 & .000 & .124 & & .000 & .000 \\
\hline \multirow{2}{*}{ POE } & $\begin{array}{c}\text { Pearson } \\
\text { Correlation }\end{array}$ & $.180^{* *}$ & .084 & .081 & $.241^{* *}$ & 1 & $.559^{* *}$ \\
\hline & Sig. (2-tailed) & .001 & .134 & .147 & .000 & & .000 \\
\hline \multirow{2}{*}{$\underset{\text { AL }}{\text { TOT }}$} & $\begin{array}{c}\text { Pearson } \\
\text { Correlation }\end{array}$ & $.619^{* * *}$ & $.573^{* *}$ & $.505^{* *}$ & $.621^{* *}$ & $.559^{* * *}$ & 1 \\
\hline & Sig. (2-tailed) & .000 & .000 & .000 & .000 & .000 & \\
\hline
\end{tabular}

**. Correlation is significant at the 0.01 level (2-tailed).

*. Correlation is significant at the 0.05 level (2-tailed). 


\section{What are students' environmental paradigms?}

Below is an overall description of the Kuwait University students' environmental paradigms, as determined by providing percentage distributions, mean scores, and standard deviations of their NEP scores (see Table 3).

Table (3): Percentage, Mean, and Standard Deviation Distributions of NEP Scale Items*

\begin{tabular}{|c|c|c|c|c|c|c|c|}
\hline \multirow{2}{*}{ No. } & \multirow{2}{*}{ Item } & \multicolumn{4}{|c|}{$\%$ Distribution } & \multirow[t]{2}{*}{ Mean } & \multirow[t]{2}{*}{ Std. } \\
\hline & & SD & D & $\mathbf{A}$ & SA & & \\
\hline 1 & $\begin{array}{l}\text { We are approaching the } \\
\text { limit of the number of } \\
\text { people that the earth can } \\
\text { support. }\end{array}$ & 0.6 & 8.7 & 58.4 & 32.3 & 3.22 & 0.621 \\
\hline 2 & $\begin{array}{l}\text { Humans have the right to } \\
\text { modify the natural } \\
\text { environment to suit their } \\
\text { needs. }\end{array}$ & 1.2 & 16.5 & 46.0 & 36.3 & 3.17 & 0.741 \\
\hline 3 & $\begin{array}{l}\text { When humans interfere } \\
\text { with nature, it often } \\
\text { produces disastrous } \\
\text { consequences. }\end{array}$ & $\mathbf{0}$ & 4.7 & 39.4 & 55.9 & 3.51 & 0.587 \\
\hline 4 & $\begin{array}{l}\text { Human ingenuity will } \\
\text { ensure that we do not } \\
\text { make the earth unlivable. }\end{array}$ & 1.6 & 10.2 & 47.8 & 40.4 & 3.27 & 0.705 \\
\hline 5 & $\begin{array}{l}\text { Humans are severely } \\
\text { abusing the environment. }\end{array}$ & 4.7 & 34.2 & 48.1 & 13.0 & 2.70 & 0.753 \\
\hline 6 & $\begin{array}{l}\text { The earth has plenty of } \\
\text { natural resources if we just } \\
\text { learn how to develop them. }\end{array}$ & 8.1 & 42.2 & 32.3 & 17.4 & 2.59 & 0.868 \\
\hline 7 & $\begin{array}{l}\text { Plants and animals have as } \\
\text { much right as humans do } \\
\text { to exist. }\end{array}$ & 5.6 & 23.9 & 51.6 & 18.9 & 2.84 & 0.792 \\
\hline
\end{tabular}




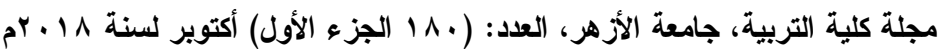

\begin{tabular}{|c|c|c|c|c|c|c|c|}
\hline \multirow{2}{*}{ No. } & \multirow{2}{*}{ Item } & \multicolumn{4}{|c|}{ \% Distribution } & \multirow[t]{2}{*}{ Mean } & \multirow[t]{2}{*}{ Std. } \\
\hline & & SD & D & $\mathbf{A}$ & SA & & \\
\hline 8 & $\begin{array}{l}\text { The balance of nature is } \\
\text { strong enough to cope with } \\
\text { the impacts of modern } \\
\text { industrial nations. }\end{array}$ & 0.6 & 5.9 & 50.9 & 42.5 & 3.35 & 0.621 \\
\hline 9 & $\begin{array}{l}\text { Despite our special } \\
\text { abilities, humans are still } \\
\text { subject to the laws of } \\
\text { nature. }\end{array}$ & 14.3 & 25.5 & 41.3 & 18.9 & 2.65 & 0.946 \\
\hline 10 & $\begin{array}{l}\text { The so-called "ecological } \\
\text { crisis" facing humankind } \\
\text { has been greatly } \\
\text { exaggerated. }\end{array}$ & 2.2 & 14.0 & 55.9 & 28.0 & 3.10 & 0.706 \\
\hline 11 & $\begin{array}{l}\text { The earth is a closed } \\
\text { system with very limited } \\
\text { room and resources. }\end{array}$ & 2.2 & 14.9 & 53.4 & 29.5 & 3.10 & 0.723 \\
\hline 12 & $\begin{array}{l}\text { Humans were meant to } \\
\text { rule over the rest of } \\
\text { nature. }\end{array}$ & 41.3 & 46.9 & 8.1 & 3.7 & 1.74 & 0.760 \\
\hline 13 & $\begin{array}{l}\text { The balance of nature is } \\
\text { very delicate and easily } \\
\text { upset. }\end{array}$ & 1.9 & 11.8 & 48.4 & 37.9 & 3.22 & 0.723 \\
\hline 14 & $\begin{array}{l}\text { Humans will eventually } \\
\text { learn enough about how } \\
\text { nature works to be able to } \\
\text { control it. }\end{array}$ & 9.9 & 41.0 & 34.8 & 14.3 & 2.53 & 0.858 \\
\hline 15 & $\begin{array}{l}\text { If things continue on their } \\
\text { present course, we will } \\
\text { soon experience a major } \\
\text { ecological catastrophe. }\end{array}$ & 9.0 & 36.6 & 37.6 & 16.8 & 2.62 & 0.868 \\
\hline
\end{tabular}


For even-numbered questions, disagreement represented a pro-ecological view. For odd-numbered questions, agreement represented a pro-ecological view.

3. Which of the five NEP facets had the highest level among Kuwait University students?

To determine the highest NEP facet level among Kuwait University students, the percentage distributions, mean scores, and standard deviations for each NEP facet were were found (see Tables 4, 5, 6, 7, and 8).

\section{The Reality of Limits to Growth:} Table 4).

This NEP facet addressed limits to population growth (see

Table 4. Frequency and Mean Distribution of Reality of Limits to Growth

\begin{tabular}{|l|l|c|c|c|c|c|c|}
\hline \multirow{2}{*}{ No. } & \multicolumn{2}{|c|}{ Item } & \multicolumn{3}{c|}{ \% Distribution } & \multirow{2}{*}{ Mean } & Std. \\
\cline { 2 - 7 } & SD & D & A & SA & & \\
\hline 1 & $\begin{array}{l}\text { We are approaching the } \\
\text { limit of the number of } \\
\text { people that the earth } \\
\text { can support. }\end{array}$ & 0.6 & 8.7 & 58.4 & 32.3 & 3.22 & 0.621 \\
\hline 6 & $\begin{array}{l}\text { The earth has plenty of } \\
\text { natural resources if we } \\
\text { just learn how to } \\
\text { develop them. }\end{array}$ & 8.1 & 42.2 & 32.3 & 17.4 & 2.59 & 0.868 \\
\hline 11 & $\begin{array}{l}\text { The earth is a closed } \\
\text { system with very } \\
\text { limited room and } \\
\text { resources. }\end{array}$ & 2.2 & 14.9 & 53.4 & 29.5 & 3.10 & 0.723 \\
\hline & $\begin{array}{l}\text { Reality of Limits to } \\
\text { Growth }\end{array}$ & 3.63 & 21.90 & 48.03 & 26.4 & 2.97 & 0.44 \\
\hline
\end{tabular}

The above Table (4) indicates that a majority of the students $(90.7 \%)$ embraced beliefs about the population carrying capacity of the earth (Item 1$)$, while $(9.3 \%)$ believed the opposite. The Table also states that the great majority of students $(\mathbf{8 2 . 9 \%})$ supported the notion that the earth is a closed system with very limited room and resources (Item 11), while a few (17.1\%) took 
the opposite view. However, $49.7 \%$ of the students accepted the idea of unlimited resources on the earth and humans' unfettered ability to learn to use them (Item 6), while $50.3 \%$ rejected that view.

\section{Anti-anthropocentrism} Table 5).

This NEP facet dealt with anti-anthropocentrism (see

Table 5. Frequency and Mean Distribution of Antianthropocentris

\begin{tabular}{|c|c|c|c|c|c|c|c|}
\hline \multirow[t]{2}{*}{ No } & \multirow{2}{*}{ Item } & \multicolumn{4}{|c|}{ \% Distribution } & \multirow[t]{2}{*}{ Mean } & \multirow[t]{2}{*}{ 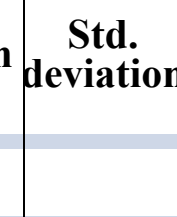 } \\
\hline & & SD & D & $\mathbf{A}$ & SA & & \\
\hline 2 & $\begin{array}{l}\text { Humans have the right to } \\
\text { modify the natural } \\
\text { environment to suit their } \\
\text { needs. }\end{array}$ & 1.2 & 16.5 & 46.0 & 36.3 & 3.17 & 0.741 \\
\hline 7 & $\begin{array}{l}\text { Plants and animals have } \\
\text { as much right as humans } \\
\text { do to exist. }\end{array}$ & 5.6 & 23.9 & 51.6 & 18.9 & 2.84 & 0.792 \\
\hline 12 & $\begin{array}{l}\text { Humans were meant to } \\
\text { rule over the rest of } \\
\text { nature. }\end{array}$ & 41.3 & 46.9 & 8.1 & 3.7 & 1.74 & 0.760 \\
\hline & Anti-anthropocentrism & 16.0 & 29.1 & 35.2 & 19.6 & 2.58 & 0.450 \\
\hline
\end{tabular}

The above Table (5) shows that the participants' ecological paradigms concerning anti-anthropocentrism were acceptable. This indicates that majority of students $(\mathbf{8 8 . 2 \%})$ did not look upon humans as rulers over nature (Item 12), while $11.8 \%$ believed the opposite. The right of existence for both plants and animals equaling that of humans (Item 7) was supported by $70.5 \%$ of the students, while $29.5 \%$ held the opposing view. A greater portion of those sampled $(82.3 \%)$ believed that humans should have the right to modify the natural environment to suit their needs (Item 2), which was opposite to the NEP view. 


\section{The Fragility of Nature's Balance:}

This NEP facet addressed the fragility of nature's balance.

Table (6): Frequency and Mean Distribution of the Fragility of Nature's Balance

\begin{tabular}{|l|l|l|l|l|l|l|l|}
\hline \multirow{2}{*}{ No. Item } & \multicolumn{3}{|c|}{$\%$} & Mean & Std. \\
\cline { 2 - 7 } & SD & D & A & SA & & \\
\hline 3 & $\begin{array}{l}\text { Humans have the right } \\
\text { to modify the natural } \\
\text { environment to suit } \\
\text { their needs. }\end{array}$ & 0 & 4.7 & 39.4 & 55.9 & 3.51 & 0.587 \\
\hline 8 & $\begin{array}{l}\text { The balance of nature is } \\
\text { strong enough to cope } \\
\text { with the impacts of } \\
\text { modern industrial } \\
\text { nations. }\end{array}$ & 0.6 & 5.9 & 50.9 & 42.5 & 3.35 & 0.621 \\
\hline 13 & $\begin{array}{l}\text { The balance of nature is } \\
\text { very delicate and easily } \\
\text { upset. }\end{array}$ & 1.9 & 11.8 & 48.4 & 37.9 & 3.22 & 0.723 \\
\hline & $\begin{array}{l}\text { Fragility of Nature's } \\
\text { Balance }\end{array}$ & .83 & 7.47 & 46.2 & 45.43 & 3.36 & 0.412 \\
\hline
\end{tabular}

The NEP includes the idea that the balance of nature is fragile and threatened by human interference. The above Table (6) shows that $95.3 \%$ of students agreed that human intervention in nature often produces disastrous consequences (Item 3), while 4.7\% believed the contrary. The Table also shows that $86.3 \%$ of students agreed that the balance of nature is very delicate and easily upset (Item 13), while $13.7 \%$ disagreed with this assertion. It was also found that a vast majority of the students $(93.4 \%)$ agreed that the balance of nature was strong enough to cope with the impact of modern industry (Item 8), while 6.6\% opposed this idea. 


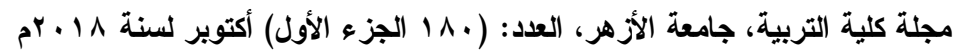

\section{Rejection of Exemptionalism":}

This NEP facet considered anti-exemptionalism.

Table (7): Frequency and Mean Distribution of the Rejection of Exemptionalism

\begin{tabular}{|l|l|c|c|c|c|c|c|}
\hline \multirow{2}{*}{ No. } & \multicolumn{1}{|c|}{ Item } & \multicolumn{3}{|c|}{$\%$ Distribution } & \multirow{2}{*}{ Mean } & Std. \\
\cline { 3 - 7 } & & SD & D & A & SA & & \\
\hline 4 & $\begin{array}{l}\text { Human ingenuity will } \\
\text { ensure that we do not } \\
\text { make the earth } \\
\text { unlivable. }\end{array}$ & 1.6 & 10.2 & 47.8 & 40.4 & 3.27 & 0.705 \\
\hline 9 & $\begin{array}{l}\text { Despite our special } \\
\text { abilities, humans are } \\
\text { still subject to the laws } \\
\text { of nature. }\end{array}$ & 14.3 & 25.5 & 41.3 & 18.9 & 2.65 & 0.946 \\
\hline 14 & $\begin{array}{l}\text { Humans will } \\
\text { eventually learn } \\
\text { enough about how } \\
\text { nature works to be } \\
\text { able to control it. }\end{array}$ & 9.9 & 41.0 & 34.8 & 14.3 & 2.53 & 0.858 \\
\hline & $\begin{array}{l}\text { Rejection of } \\
\text { Exemptionalism }\end{array}$ & 8.6 & 25.57 & 41.3 & 24.5 & 2.82 & 0.478 \\
\hline
\end{tabular}

exemptionalism, which is based on the worldview that humans are exempt from the constraints of nature (Erdogan, 2009).

Table (7) shows that $88.2 \%$ of the study sample believed that human ingenuity would ensure that we do not make the earth unlivable (Item 4 ), while $11.8 \%$ rejected this view. The Table also shows that $60.2 \%$ of the sample believed that despite humans' special abilities, they are still subject to the laws of nature (Item 9); 39.8\% rejected that view. Of the total, $50.9 \%$ opposed the idea that humans will eventually learn enough about how nature works to be able to control it (Item 14), while $49.1 \%$ believed that this would come to pass. 


\section{Possibility of an Eco-crisis:} (see Table 8).

This NEP facet encompassed the possibility of an eco-crisis

Table (8): Frequency and Mean Distribution of the Possibility of an Eco-crisis

\begin{tabular}{|c|c|c|c|c|c|c|c|}
\hline \multirow{2}{*}{ No. } & \multirow{2}{*}{ Item } & \multicolumn{4}{|c|}{ \% Distribution } & \multirow{2}{*}{ Mean } & \multirow{2}{*}{ Std. } \\
\hline & & SD & D & $\mathbf{A}$ & SA & & \\
\hline 5 & $\begin{array}{l}\text { Humans are } \\
\text { severely abusing the } \\
\text { environment. }\end{array}$ & 4.7 & 34.2 & 48.1 & 13.0 & 2.70 & 0.753 \\
\hline 10 & $\begin{array}{l}\text { The so-called } \\
\text { "ecological crisis" } \\
\text { facing humankind } \\
\text { has been greatly } \\
\text { exaggerated. }\end{array}$ & 2.2 & 14.0 & 55.9 & 28.0 & 3.10 & 0.706 \\
\hline 15 & $\begin{array}{l}\text { If things continue on } \\
\text { their present course, } \\
\text { we will soon } \\
\text { experience a major } \\
\text { ecological } \\
\text { catastrophe. }\end{array}$ & 9.0 & 36.6 & 37.6 & 16.8 & 2.62 & 0.868 \\
\hline & $\begin{array}{l}\text { Possibility of an } \\
\text { Eco-crisis }\end{array}$ & 6.7 & 10.3 & 55.9 & 28.0 & 2.80 & 0.457 \\
\hline
\end{tabular}

The above Table 9 illustrates that the majority of the sample $(61.1 \%)$ either strongly agreed $(13.0 \%)$ or agreed $(48.1 \%)$ with the statement regarding humans' abuse of nature (Item 5). Regarding the probability of an ecological catastrophe (Item 15), almost $54.4 \%$ of the sample agreed that society's present course is unsustainable, while $45.6 \%$ disagreed. Conversely, the sample either strongly agreed $(28.0 \%)$ or agreed $(55.9 \%)$ with the statement that the ecological crisis has been greatly exaggerated (Item 10), while $17.0 \%$ opposed this view. 
4. What was the significance of the impact of students' exposure to courses about environment on their environmental paradigms?

This was determined by using one-way ANOVA test analyses (see Table 9).

Table (9): One-way ANOVA Test Results According to exposure to courses on the environment

\begin{tabular}{|c|c|c|c|c|c|c|}
\hline & & $N$ & Mean & Std. & $F$ & $p$-value \\
\hline \multirow{3}{*}{$\begin{array}{l}\text { Reality of } \\
\text { Limits to } \\
\text { Growth }\end{array}$} & $\begin{array}{c}\text { Have master } \\
\text { degree in } \\
\text { environmental } \\
\text { science. }\end{array}$ & 122 & 3.01 & 0.470 & \multirow{3}{*}{2.53} & \multirow{3}{*}{0.08} \\
\hline & $\begin{array}{c}\text { Have one } \\
\text { environmental } \\
\text { course }\end{array}$ & 100 & 3.00 & 0.422 & & \\
\hline & $\begin{array}{c}\text { No } \\
\text { environmental } \\
\text { course }\end{array}$ & 100 & 2.89 & 0.421 & & \\
\hline \multirow{3}{*}{$\begin{array}{l}\text { Anti- } \\
\text { anthropocent } \\
\text { rism }\end{array}$} & $\begin{array}{c}\text { Have master } \\
\text { degree in } \\
\text { environmental } \\
\text { science. }\end{array}$ & 122 & 2.59 & 0.487 & \multirow{3}{*}{4.29} & \multirow{3}{*}{0.06} \\
\hline & $\begin{array}{c}\text { Have one } \\
\text { environmental } \\
\text { course }\end{array}$ & 100 & 2.64 & 0.427 & & \\
\hline & $\begin{array}{c}\text { No } \\
\text { environmental } \\
\text { course }\end{array}$ & 100 & 2.64 & 0.409 & & \\
\hline $\begin{array}{c}\text { Fragility of } \\
\text { Nature's } \\
\text { Balance }\end{array}$ & $\begin{array}{c}\text { Have master } \\
\text { degree in } \\
\text { environmental } \\
\text { science. }\end{array}$ & 122 & 3.40 & 0.373 & 1.60 & 0.20 \\
\hline
\end{tabular}




\begin{tabular}{|c|c|c|c|c|c|c|}
\hline & & $N$ & Mean & Std. & $F$ & $p$-value \\
\hline & $\begin{array}{c}\text { Have one } \\
\text { environmental } \\
\text { course }\end{array}$ & 100 & 3.38 & 0.426 & & \\
\hline & $\begin{array}{c}\text { No } \\
\text { environmental } \\
\text { course }\end{array}$ & 100 & 3.30 & 0.440 & & \\
\hline & $\begin{array}{l}\text { Have master } \\
\text { degree in } \\
\text { environmental } \\
\text { science. }\end{array}$ & 122 & 2.81 & 0.485 & & \\
\hline $\begin{array}{l}\text { Rejection of } \\
\text { Exemptionalis } \\
\text { m }\end{array}$ & $\begin{array}{c}\text { Have one } \\
\text { environmental } \\
\text { course }\end{array}$ & 100 & 2.85 & 0.486 & 0.27 & 0.76 \\
\hline & $\begin{array}{c}\text { No } \\
\text { environmental } \\
\text { course }\end{array}$ & 100 & 2.80 & 0.464 & & \\
\hline & $\begin{array}{c}\text { Have master } \\
\text { degree in } \\
\text { environmental } \\
\text { science. }\end{array}$ & 122 & 2.87 & 0.436 & & \\
\hline $\begin{array}{l}\text { Possibility of } \\
\text { Eco-crisis }\end{array}$ & $\begin{array}{c}\text { Have one } \\
\text { environmental } \\
\text { course }\end{array}$ & 100 & 2.73 & 0.462 & 2.46 & 0.09 \\
\hline & $\begin{array}{c}\text { No } \\
\text { environmental } \\
\text { course }\end{array}$ & 100 & 2.80 & 0.469 & & \\
\hline
\end{tabular}

Table (9) shows the Anova test results according to participants' exposure to environmental courses. There were no statistically significant differences among specialization groups with regards to Reality of Limits to Growth; Antianthropocentrism; Fragility of Nature's Balance; Rejection of Exemptionalism; and Possibility of an Eco-crisis. 


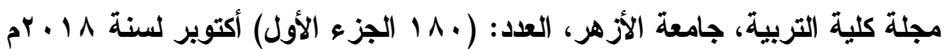

5. What was the significance of students' gender on their environmental paradigms?

This was determined using $t$-test analyses (see Table 10).

Table (10): The $t$-test Results According to Gender

\begin{tabular}{|c|c|c|c|c|c|c|}
\hline Facet & $\underset{\mathbf{r}}{\text { Gende }}$ & $N$ & Mean & Std. & $t$-test & $p$-value \\
\hline \multirow{2}{*}{$\begin{array}{l}\text { Reality of Limits to } \\
\text { Growth }\end{array}$} & $\mathbf{F}$ & 224 & 2.96 & 0.449 & \multirow{2}{*}{0.566} & \multirow{2}{*}{0.572} \\
\hline & M & 98 & 2.99 & 0.431 & & \\
\hline \multirow{2}{*}{$\begin{array}{l}\text { Anti- } \\
\text { anthropocentrism }\end{array}$} & $\mathbf{F}$ & 224 & 2.56 & 0.445 & \multirow{2}{*}{1.713} & \multirow{2}{*}{0.088} \\
\hline & M & 98 & 2.65 & 0.458 & & \\
\hline \multirow{2}{*}{$\begin{array}{l}\text { Fragility of Nature's } \\
\text { Balance }\end{array}$} & $\mathbf{F}$ & 224 & 3.37 & 0.385 & \multirow{2}{*}{0.472} & \multirow{2}{*}{0.637} \\
\hline & M & 98 & 3.35 & 0.469 & & \\
\hline \multirow{2}{*}{$\begin{array}{l}\text { Rejection of } \\
\text { Exemptionalism }\end{array}$} & $\mathbf{F}$ & 224 & 2.80 & 0.472 & \multirow{2}{*}{0.892} & \multirow{2}{*}{0.373} \\
\hline & $\mathbf{M}$ & 98 & 2.85 & 0.491 & & \\
\hline \multirow{2}{*}{$\begin{array}{l}\text { Possibility of an Eco- } \\
\text { crisis }\end{array}$} & $\mathbf{F}$ & 224 & 2.85 & 0.423 & \multirow{2}{*}{2.814} & \multirow{2}{*}{0.04} \\
\hline & $\mathbf{M}$ & 98 & 2.70 & 0.511 & & \\
\hline
\end{tabular}

participants' genders. Participants' ecological paradigms significantly differed with regards the Possibility of an Eco-crisis, where the mean for females was higher than that for males. However, no significant differences emerged with regards to Antianthropocentrism, Reality of Limits to Growth, Fragility of Nature's Balance, and Rejection of Exemptionalism

\section{Discussion:}

The aim of this study was to explore and examine Kuwait University students' environmental beliefs, as manifested in their environmental paradigms. The Arabic copy of NEP has been tested and used in new socio-culture context generating a broad base of knowledge about individuals' values, beliefs, and 
perceptions concerning the natural world and humanity's place therein.

In addition, It also determined which of the five facets included in the NEP scale were predominant and addressed differences that can be attributed to two relevant categorical variables: gender and students' exposure to courses about the environment. The results show that the majority of these students dual ecological view. This is especially true for questions related to the Reality of Limits to Growth and the Possibility of an Ecocrisis, the two highest scoring categories (see Table 1). However, there were five items $(2,4,8,10$, and 14$)$ in which the majority of respondents did not support pro-ecological beliefs. This dual paradigm seems to be consequence of Kuwait cultural context might be complete the overall picture of the study results. Thus, it could be argued that the fundamental nature of the economic conditions, religion, and education, in way or another, has contributed to dual environmental paradigm. Why, Kuwaitis have become empowered with the means to enjoy a high standard of living that is easily achieved since most of their necessities such education, housing, health care, water, electricity, phones, gas, and food staff either are provided for them, at heavily subsided rates or free of charge. Given the high standard of living enjoyed by Kuwaitis, unplanned factors alone might determine which attitude, beliefs or paradigm would have accordingly. Therefore, it seems that these Kuwait University students' environmental paradigms were constructive (i.e., ready to be built upon) and their worldview multi-faceted with regards to environmental issues, showing their sensitivity to the complexity of the subject; when taken in total, this is positive. Such results align with much of the research on this topic (e.g., Alibeli \& White, 2011). However, Erdogan (2009) found that most university students in Turkey were hesitant to embrace the issue of environmental sensitivity.

This study also offers several insights as regards the five most predominant NEP facets and their reception by students. With regards to the Reality of Limits to Growth, the majority of the students believed that humans were approaching the limit of the number of people that the earth could support. They also supported the idea that the earth is a closed system with very limited room and resources. In addition, they understood the earth's resources to be limited and thus felt there was a human need to better learn how to use them.

Concerning Anti-anthropocentrism (i.e., the belief that human beings have the right to modify and control the natural environment), the findings reveal that students recognized humans as embedded in the ecosphere and evolving alongside 


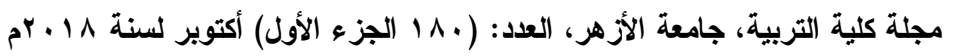

other species, rather than consciously understanding the process of evolution. Their ecological consciousness was moving towards development; they had at least some understanding that nature was not created solely for the benefit of humanity. In addition, they did not accept the idea that humans have the right to modify the natural environment to suit their own needs, or that nature exists primarily for human use and has no inherent value of its own. Nor did they embrace the Anti-anthropocentric statement regarding plants' and animals' right to exist.

In terms of the Fragility of Nature's Balance, the belief that human activities impact the balance of nature, this study determined that a great majority of the students believed that when humans interfere with nature, it often produces disastrous consequences, but also that the balance of nature is strong enough to cope with the impacts of modern industry. Therefore, the balance of nature is very delicate and easily upset, but strong enough to withstand substantial impact. These results agree with those of Erdogan (2009), who addressed anti-anthropocentric statements about the right of existence of plants and animals; however, our findings were in contrast to those of Devall (2007), who considered humanity to be an integral part of nature and not dominant over or apart from it. Devall (2007) added that massive human-induced disruptions of ecosystems were unethical and harmful to humankind; designs for human settlements should be in harmony with nature, and not against it. Similarly, Erdogan (2009) opposed the idea that nature exists primarily for human use and has no inherent value of its own, or that humans have the right to modify the natural environment to suit their needs.

For The Rejection of Exemptionalism, the belief that humans are not exempt from the constraints of nature, the results indicate that the majority of the students did have exemptionalist views. The NEP worldview assumes that people reject the idea that humans are exempt from the constraints of nature, that human actions and economics exist outside of and above nature. At least half of students queried for this research indicated that they did not have an anti-exemptionalist worldview, and instead believed that humans would eventually learn enough about how nature works to be able to control it. It seems that many of those surveyed trusted in human ingenuity and the ability to overcome the constraints of nature. However, over half of the students also believed that despite our special abilities, humans are still subject to laws of nature.

Finally, concerning the Possibility of an Eco-crisis, the view that humans are causing detrimental harm to the physical environment, the majority of Kuwait University students agreed that humans were severely abusing the environment and that an 
ecological catastrophe was likely, but also that the nature of the ecological crisis facing humankind had been greatly exaggerated. The NEP stresses human dependence on nature and the likely disastrous outcome of humans interfering with it. Naess (2008) found that supporters of the "deep ecology movement" embraced its principles as a result of a deep questioning of mainstream values, beliefs, and practices, which aligned with the results of the current research.

The findings in the current research regarding the effects of degree of exposure to courses on environmental paradigms show that they did not have a statistically significant effect. The results of the study challenge the traditional environmental education model from the $1980 \mathrm{~s}$, which holds that environmental literacy advances in stages, from knowledge to attitudes and finally to behavior. Behavioral changes among students seem to be easier to achieve than changes in paradigm through conventional educational strategies of influence. Paradigm shift is complex cognitive and affective processes that are slow to develop. The theory of social constructivism can provide some explanations for these findings. According to the theory, paradigms are socially constructed, and people need to be involved in their learning processes. The teacher-center instructions and pedagogy, which is still widely implemented by public schools and Universities in Kuwait, does not promote social construction for proenvironmental paradigm among students; rather, it fosters certain knowledge and awareness through a behaviorist approach to education. (Umit, Dogan, Osman, Utku, Duygu, \& Mehmet, 2013).

Further, the findings regarding gender showed that it did not have a significant effect on the students' ecological paradigms. This result agrees with those of Demirel and colleagues (2009) and contradicted those of other studies (Rideout et al., 2005; ; Ustun et al., 2013). Accordingly, it can be asserted that concerns about the environment vary from one country to another, in response to the effects of demographic variables and socio-economic characteristics, as well as individual experience.

\section{Conclusions and recommendations:}

Understanding students' environmental paradigms and the adoption of pro-environmental beliefs will be a critical effort in 21st century. Lasting, positive change in humanity's treatment of the environment may not occur until environmentally supportive paradigms replace the underlying paradigms that produce current ecologically destructive actions, requiring a paradigm shift. For that, students must first undergo a serious change in thought, mind, and point of view that will then be reflected in its administrative and social structures. This research recommends a 
curriculum specifically designed to change learners' behavior through the use of action-based pedagogy that encourages students to evolve and engage with challenging projects, especially where they are called upon to investigate, evaluate, reflect upon, and assess their own impact on the environment. In addition, future work in this area should apply a mixed-methods approach (i.e., both qualitative and quantitative) to identify the informational background of and level of conscientiousness regarding important issues such as life on earth and practically sustainable developments. This will offer deeper insights into the problem of the misinterpretation of verbatim scales.

Moreover, considering the cultural context will provide common ground for understanding ecology as a component of religiosity. The broad religious orientation of a region likely affects the levels of such paradigms and the value placed on action. Further studies relating to educational practices and activities are highly recommended to ensure a greater understanding of and wider interest in this vital issue. Finally, we suggest the use of adaptive learning through projects and activities, as well as the provision of more exposure to nature and wildlife. Such techniques will most likely enhance people's feelings about nature, and help them to reconnect with other living species with which they share an ecosystem. This is likely to be very effective in raising students' consciousness and conditioning how they demonstrate their new responsiveness, turning knowledge into action. 


\section{References:}

Abdussalam, M. (2010). Islam and environmental conservation. Journal of the Muslim soldier.

Alagoz, B. \& Akman, O. (2016). Anthropocentric or ecocentric environmentalism? Views of university students. Higher Education Studies, 6(4), 34.

Al-Damkhi, A. M. (2008). Environmental ethics in Islam: Principles, violations, and future perspectives. International Journal of Environmental Studies, 65(1), 1131. http://doi.org/10.1080/00207230701859724

Alibeli, M. A. \& White, N. R. (2011). The structure of environmental concern. International Journal of Business and Social Science, 2(4), 1-8.

Al Kandari, A. H. (2016). Enhancing the acquisition of environmental cognitive and metacognitive knowledge through asynchronies discussion. Journal of The Gulf and Arabian Peninsula studies, 162(2), 187-233.

Ardahan, F. (2012). Comparison of the new ecological paradigm (NEP) scale's level of participants and non-participants of outdoor sports with respect to some demographic variables: Turkey case. TOJRAS: The Online Journal of Recreation and Sport, 1(3), 8-18.

Bagader, A. A., El-Sabbagh, A., Al-Glayand, M., Samarrai, M., \& Llewellyn, O. (1991). Islamic principles for the conservation of the natural environment. (IUCN Environmental Policy and Law Paper: No. 20 1-134).

Buckler, C. \& Creech, H. (2014). Shaping the future we want: UN decade of education for sustainable development. UNESCO.

Condrea, P. \& Bostan, I. (2008). Environmental Issues from an economic perspective. Environmental Engineering and Management Journal, 7(6), 843-849.

Covey, S. (2008). The Eight (8th) Habit. New York: Free Press.

Daramola, A. \& Ibem, E. O. (2010). Urban environmental problems in Nigeria: Implications for sustainable development. Journal of Sustainable Development in Africa, 12(1), 124-145.

Demian M. (2000). The environment audit. Financial Audit Magazine, 1,15-22. 


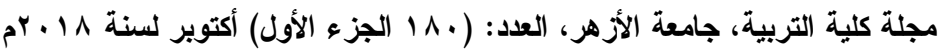

Demirel, M., Gurbuz, B., \& Karakucuk, S., (2009). Effects of recreational activities participation on environmental attitudes and reliability and validity of new ecological paradigm scale. SPORMETRE: Beden Ĕ̈itimi ve Spor Bilimleri Dergisi, 7(2), 47-50.

Devall, B. \& Sessions, G. (2007). Deep ecology: Living as if nature mattered. Layton: Gibbs Smith.

Dunlap, R. E. (2008). The new environmental paradigm scale: From marginality to worldwide use. The Journal of Environmental Education, 40(1), 3-18.

Dunlap, R. E. \& van Liere, K. D. (1978). The new environmental paradigm. The Journal of Environmental Education, 9, 1019.

Erdogan, N. (2009). Testing the new ecological paradigm scale: Turkish case. African Journal of Agricultural Research, 4(10), 1023-1031.

Hafezi, S., Shobiri, S. M., Sarmadi, M. R., \& Abass, E. (2013). Novel of environmental Communal education: Content analysis based on distance education approach. Turkish Online Journal of Distance Education: TOJDE, 14(1), 13.

Hammink, W. (2012) Mother nature and the heavenly father: Christianity and the environment in a globalized world. Macalester International, 30(9). Available at: http://digitalcommons.macalester.edu/macintl/vol30/iss1/9

Hawcroft, J. \& Milfont, T. (2010). The use (and abuse) of the new environmental paradigm scale over the last 30 years: A meta-analysis. Journal of Environmental psychology, 30(2), 143-158.

Islam, M. N. \& Islam, M. S. (2015). Human-animal relationship: Understanding animal rights in the Islamic ecological paradigm. Journal for the Study of Religions and Ideologies, 14(41), 96.

Islam, M. S. \& Islam, M. N. (2016). Environmentalism of the poor: The Tipaimukh dam, ecological disasters and environmental resistance beyond borders. Bandung: Journal of the Global South, 3(1), 27.

Grimmette, K. A. (2014). The impacts of environmental education on youth and their environmental awareness. (Unpublished undergraduate thesis). University of Nebraska, Lincoln. 


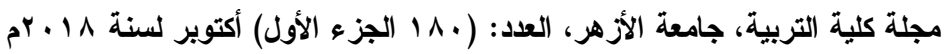

Husain, A. (2017). The narrative of environmentalism in Kuwait. (Unpublished doctoral dissertation). Oregon State University.

Kaiser, F. G. \& Biel, A. (2000). Assessing general ecological behavior: A cross-cultural comparison between Switzerland and Sweden. European Journal of Psychological Assessment, 16(1), 44.

Kalavathy, S. (2004). Environmental studies. Tiruchirappalli, India: Bishop Heber College.

Kamla, R., Gallhofer, S., \& Haslam, J. (2006). Islam, nature and accounting: Islamic principles and the notion of accounting for the environment. Accounting Forum, 30(3), 245-265.

Knight, M. H., Seddon, P. J., \& Midfa, A. A. (2011). Transboundary conservation initiatives and opportunities in the Arabian Peninsula. Zoology in the Middle East, 54(3), 183-195.

Kumud, G. (2014). Environmental awareness among secondary school students of Golaghat district in the state of Assam and their attitude towards environmental education. Journal of Humanities and Social Science: IOSR-JHSS, (19)3, 30-34.

Lotz-Sisitka, H. (2015). UNESCO World Conference on Education for Sustainable Development Conference Report. Retrieved from: $\quad$ http://www.unesco.org/new/en/unesco-worldconference-on-esd-2014

Maloney, M. P., Ward, M. P., \& Braucht, G. N. (1975). A revised scale for the measurement of ecological attitudes and knowledge. American Psychologist, 30(7), 787.

Mayer, F. S. \& Frantz, C. M. (2004). The connectedness to nature scale: A measure of individuals' feeling in community with nature. Journal of Environmental Psychology, 24(4), 503-515.

Messiou, K. (2017). Research in the field of inclusive education: time for a rethink?. International journal of inclusive education, 21(2), 146-159.

Muhsin, M. K. (2009). Sahih Bukhari. M. K. Muhsin (Trans.). Mika'il Al-Almany (Ed.).

Mulà, I. \& Tilbury, D. (2009). A United Nations decade of education for sustainable development (2005-2014): What difference will it make? Journal of Education for Sustainable Development, 3(1), 101-111. 


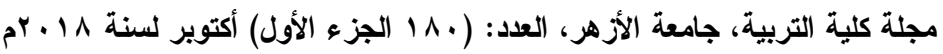

Mulà, I. \& Tilbury, D. (2009). Progress and Possibilities for the UN Decade of Education for Sustainable Development (DESD) in EU Member States: An OECD ENSI and French National Commission for DESD Report. Cheltenham, UK: ENSI.

Naess, A. (2008). The shallow and the deep ecology movement. The Trumpeter: Journal of Ecosophy, 24(1), 56-67.

Norris I. E. \& Juliet U. D. (2016). Impact of environmental education on the knowledge and attitude of students towards the environment. International Journal of Environmental \& Science Education, 11(12), 5367-5375.

Olofsson, A. \& Ohman, S. (2006). General beliefs and environmental concern: Transatlantic comparison. Environment and Behavior, 38(6), 768-790.

Ozden, M. (2008). Environmental awareness and the attitudes of student teachers: An empirical research. International Research in Geographical \& Environmental Education, 17(1), 40-55.

Plottu E. \& Plottu, B. (2007). The concept of total economic value of environment: A reconsideration within a hierarchical rationality. Environmental Economics, 61, 52-61.

Putrawan, I. M. (2015). Measuring new environmental paradigm based on students' knowledge about ecosystem and locus of control. Eurasia Journal of Matbematics, Science $\mathcal{E}$ Technology Education, 11(2), 325-333.

Rexeisen, R. \& Roffler, T. (2006). A longitudinal study of the impact of study abroad experiences on attitudes towards the environment. Second International Conference on Environmental, Cultural, Economic, and Social Sustainability.

Rice, G. (2006). Pro-environmental behavior in Egypt: Is there a role for Islamic environmental ethics? Journal of Business Ethics, 65(4), 373-390. Available at: http://doi.org/10.1007/s10551-006-0010-9.

Rideout, B. E. (2014). The liberal arts and environmental awareness: Exploring endorsement of an environmental worldview in college students. International Journal of Environmental \& Science Education, 9, 59-76.

Rideout, B. E., Hushen, K., McGinty, D., Perkins, S., \& Tate, J. (2005). Endorsement of the new ecological paradigm in systematic and email samples of university students. Journal of Environmental Education, 36, 15-23. 


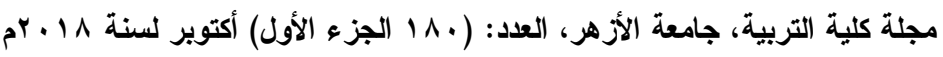

Rizk, R. R. (2014). Islamic environmental ethics. Journal of Islamic Accounting and Business Research, 5(2), 194-204. Available at: http://doi.org/10.1108/jiabr-09-2012-0060.

Sharifi, A. \& Murayama, A. (2014). Neighborhood sustainability assessment in action: Cross-evaluation of three assessment systems and their cases from the US, the UK, and Japan. Building and Environment, 72, 243-258.

Shomali, M. (2008). Aspects of environmental ethics: An Islamic perspective. Thinking Faith, 11.

Silicon India. (2012). 10 Most Valuable Currencies in the World. Retrieved from: https://en.wikipedia.org/wiki/Economy of Kuwait.

Spiess, A. (2008). Developing adaptive capacity for responding to environmental change in the Arab gulf states: Uncertainties to linking ecosystem conservation, sustainable development and society in authoritarian rentier economies. Global and Planetary Change, 64(3), 244-252.

Statistic Service System. (2015). Nationality by religion and gender. Kuwait: The Public Authority for Civil Information. Retrieved from: https://www.paci.gov.kw/stat/Default.aspx.

Strategic Planning Department: Environment. (2012). Environmental strategy of the State of Kuwait. Kuwait: Public Authority.

Taskin, O. (2009). The environmental attitudes of Turkish senior high school students in the context of postmaterialism and the new environmental paradigm. International Journal of Science Education, 31, 481-502.

Thapa, B. (1999). Environmentalism: The relation of environmental attitudes and environmentally responsible behaviors among undergraduate students. Bulletin of Science, Technology \& Society, 19, 426.

Thomson, G. \& Hoffman, J. (2003). Measuring the Success of Environmental Education Programs. Calgary, AB: Canadian Parks and Wilderness Society.

UNESCO. (2011). United Nations educational, scientific and cultural organization education from sustainable development: An expert review of processes and learning. Available from: www.unesco.org/education/desd. 
United Nations Development Programme: Kuwait. (2011). Seeking sustainability and cost efficiency: $A$ UNDP environment programme for Kuwait. Kuwait: UNDP.

Ustun, U. D., Goral, M., Demirel, M., \& Kalkavan, A., (2011). The Effects of Participation in Recreational Activities on Environmental Attitudes of School of Physical Education and Sport Students. Antalya: TAFISA World Congress.

Ustun, U. D., Gumusgul, O., Isık, U., Demırel, D. H., \& Demırel, M. (2013). A comparison of environmental values: The effect of outdoor recreation. International Journal of Sport Studies, 3(10), 1023-1029.

Weigel, R. \& Weigel, J. (1978). Environmental concern the development of a measure. Environment and behavior, 10(1), 3-15.

Wilson, J., Tyedmers, P., \& Pelot, R. (2007). Contrasting and comparing sustainable development indicator metrics. Ecological indicators, 7(2), 299-314.

World Bank. (2015). GDP per capita, PPP (current international \$). World Development Indicators Database. Retrieved from: https://en.wikipedia.org/wiki/Economy of Kuwait

Zelezny, L., Chua, P., \& Aldrich, C. (2000). Elaborating on gender differences in environmentalism. Journal of Social Issues, 56(3), 443-57. Available at: http://dx.doi.org/10.1111/0022$\underline{4537.00177}$. 